\title{
Pengaruh Persepsi Manfaat, Persepsi Kemudahan, Fitur Layanan Dan Kepercayaan Terhadap Tingkat Kepuasan Pelanggan Linkaja Di Indonesia
}

\author{
Findy Meileny ${ }^{1}$, Tri Indra Wijaksana ${ }^{2}$ \\ ${ }^{1}$ Fakultas Komunikasi dan Bisnis, Universitas Telkom, findymei15@gmail.com \\ ${ }^{2}$ Fakultas Komunikasi dan Bisnis, Universitas Telkom, \\ triindrawijaksana@telkomuniversity.ac.id
}

\begin{abstract}
ABSTRAK
Penelitian ini dilakukan untuk menganalisis bagaimana pengaruh Persepsi Manfaat, Persepsi Kemudahan, Fitur layanan, dan Kepercayaan terhadap Tingkat Kepuasan Pelanggan LinkAja di Indonesia. Data dalam penelitian dikumpulkan melalui penyebaran kuesioner dan dianalisis dengan analisis kuantitatif. Sampel yang diambil adalah 100 responden dengan teknik nonprobability sampling yaitu jenis purposive sampling. Pada penelitian ini, data diolah dengan bantuan SPSS versi 20 dengan uji Analisis Regresi Berganda. Hasil olahan SPSS 20 dari analisis deskriptif dapat disimpulkan variabel Persepsi Manfaat (X1), Persepsi Kemudahan (X2), Fitur Layanan (X3), Kepercayaan (X4) dan Tingkat Kepuasan Pelanggan (Y) berada pada kategori kurang baik. Hasil dari analisis linear berganda menyatakan pula bahwa Persepsi Manfaat (X1), Persepsi Kemudahan (X2), Fitur Layanan (X3), dan Kepercayaan (X4) berpengaruh positif dan signifikan terhadap Tingkat Kepuasan Pelanggan (Y) LinkAja di Indonesia baik secara parsial maupun simultan. Hasil lain menunjukkan pula variabel yang sangat berpengaruh terhadap kepuasan pelanggan LinkAja di Indonesia adalah variabel kepercayaan, artinya semakin baik kepercayaan yang dimiliki pelanggan maka tingkat kepuasan pelanggan semakin tinggi. Dengan demikian, perusahaan harus selalu berupaya untuk meningkatkan dan memperbaiki kepercayaan pelanggan.

Kata kunci : Persepsi Manfaat, Persepsi Kemudahan, Fitur Layanan, Kepercayaan, Kepuasan Pelanggan
\end{abstract}

\begin{abstract}
The study was conducted to knows the impact of Perceived Usefulness, Perceived Ease of Use, Service Features, and Trust on LinkAja's Customer Satisfaction in Indonesia. Data collection in this study is done with questionnaires and data analysis is using quantitative analysis. This research uses purposive sampling kind of non-probability sampling technique and coonsist of 100 respondents. The analysis tools in this study used SPSS version 20. This research uses The Multiple Linear Regression Analysis Test and descriptive analysis. Result of this study describes that Perceived Usefulness (X1), Perceived Ease of Use (X2), Service Features (X3), Trust (X4), and Customer Satisfaction $(Y)$ are in the poor category. While result of multiple linear regression in this study can be conducted the impact of Perceived Usefulness (X1), Perceived Ease of Use (X2), Service Features (X3), Trust (X4) has a positive and significant influence of LinkAja's Customer Satisfaction (Y) both partial and simultaneous. The other results obtained variables that influence LinkAja's Customer Satisfaction in Indonesia is trust variable, it means the better the trust of the customer, the level of customer satisfaction will increase. Thus, companies must always strive to improve customer trust.

Keywords: Perceived Usefulness, Perceived Ease of Use, Service Features, Trust, Customer

Satisfaction
\end{abstract}

Naskah diterima: 26-08-2020, direvisi: 07-05-2020, diterbitkan: 01-09-2020

ISSN: 2355-0295, e-ISSN: 2549-8932 


\section{PENDAHULUAN}

Saat ini, teknologi sudah berkembang cepat sehingga berdampak pada kehidupan seharihari yang selalu ada kaitannya dengan teknologi. Banyak kalangan berpendapat dengan adanya teknologi dapat membantu dalam mengatasi masalah yang sering terjadi di era digital, misalnya dalam hal pembayaran. Seiring berkembangnya zaman, masyarakat Indonesia mulai beralih menggunakan pembayaran uang elektronik dibandingkan pembayaran konvensional. Pada tahun 2014 hingga tahun 2019 terjadi peningkatan signifikan mengenai rata-rata penggunaan layanan e-money (Bank Indonesia, 2019). Hal ini menunjukkan bahwa saat ini terjadi perubahan gaya hidup masyarakat di era digital yang lebih menyukai sistem cashless.

Menurut lembaga riset (Snapcart) yang melakukan penelitian terhadap perilaku konsumen dalam bertransaksi dengan aplikasi pembayaran digital, LinkAja berada di posisi terakhir sebagai aplikasi pembayaran digital favorit diantara tiga e-money pesaingnya (Fajar, 2019). Data pengguna e-money tahun 2019 menyatakan pula bahwa LinkAja berada di ranking terakhir dengan total sebanyak 23 juta pengguna (Pusparisa, 2019). E-money LinkAja adalah peralihan TCASH yang sudah berdiri sejak tahun 2011. Hasil pra survei penelitian yang disebar ke 30 responden menyatakan mayoritas pelanggan LinkAja kurang merasa puas terhadap aplikasi tersebut dengan alasan masih ada e-money sejenis yang lebih banyak menawarkan keunggulan. Permasalahan yang dikeluhkan yaitu terkait banyaknya cashback dan promo, kelengkapan dan keunggulan fitur layanan, kinerja aplikasi, kualitas pelayanan customer service LinkAja, dan proses pengembalian dana.

Berdasarkan penjelasan diatas, penulis tertarik menggunakan teori dari penelitian Zainudin (2014) mengenai "Analisis Pengaruh Perceived Usefulness dan Perceived Ease Of Use terhadap Tingkat Kepuasan Nasabah dalam Menggunakan ATM (Studi Kasus pada Nasabah Bank Muamalat Cab. Palopo)". Perbedaan penelitian ini dengan penelitian sebelumnya yaitu pada variabel, objek, dan tempat dilakukannya penelitian. Pada penelitian ini, terdapat penambahan variabel fitur layanan dan kepercayaan. Selain itu, penelitian ini bertujuan untuk mengetahui pengaruh Persepsi Manfaat, Persepsi Kemudahan, Fitur Layanan dan Kepercayaan terhadap Tingkat Kepuasan Pelanggan LinkAja di Indonesia."

\section{KAJIAN LITERATUR}

\section{Pemasaran}

Kotler dan Keller (2016) mengemukakan istilah pemasaran sebagai suatu hal yang dilakukan oleh perusahaan untuk memenuhi kebutuhan masyarakat yang mana dapat memberikan keuntungan bagi semua pihak.

\section{TAM ( Technology Acceptance Model)}

Davis (1989) mendefinisikan TAM sebagai segala bentuk yang akan diterima oleh pengguna terhadap pemakaian sistem informasi. TAM juga memiliki tujuan untuk menggambarkan faktor apa saja yang dapat menentukan bagaimana perilaku penggunaan pada sistem informasi tersebut.

\section{Persepsi Manfaat (Perceived Usefulness)}

Davis (1989) mengemukakan perceived usefulness sebagai kepercayaan yang dimiliki seseorang dalam menggunakan teknologi dapat bermanfaat untuk meningkatkan suatu kinerja. Persepsi kegunaan menurut Davis (1989) dapat diukur melalui work more quickly, useful, increase productivity, enchance effectiveness, dan improve job performance.

\section{Persepsi Kemudahan (Perceived Ease of Use)}

Davis (1989) menjelaskan perceived ease of use adalah seberapa besar seseorang percaya bahwa menggunakan teknologi dapat dengan mudah diakses tanpa membutuhkan efforts yang banyak. Persepsi kemudahan menurut Davis (1989) dapat diukur melalui easy to learn, controllable, clear \&understable, flexible, easy to become skillful, dan easy to use . 
Fitur Layanan (Service Features)

Kotler dan Keller (2012) menjelaskan bahwa fitur adalah ciri khas produk yang dijadikan sebagai pelengkap dari fungsi produk tersebut. Thom W.A. Isliko (2008) mengemukakan fitur produk dapat diukur melalui keragaman fitur, fitur sesuai dengan harapan, dan fitur memiliki keunggulan.

\section{Kepercayaan (Trust)}

Kotler dan Keller (2016) mendefinisikan kepercayaan sebagai kesanggupan organisasi untuk dapat menciptakan hubungan dan dapat bergantung pada mitra bisnisnya, yang dipengaruhi oleh faktor interpersonal, integritas, kebaikan maupun kejujuran. Terdapat empat konstruks kepercayaan konsumen yaitu benevolence, ability, integrity, dan willing

ess to depend.

\section{Kepuasan Pelanggan (Customer Satisfaction)}

Kotler \& Keller (2012) dalam Tjiptono (2014) menjelaskan kepuasan pelanggan adalah seberapa besar perasaan seseorang dengan membandingkan kinerja atau layanan yang diperoleh apakah sesuai dengan harapan mereka. Rambat Lupiyoadi (2001:158) menyebutkan dimensi kepuasan pelanggan meliputi kualitas produk, kualitas pelayanan, emosional, harga, dan biaya.

\section{Kerangka Pemikiran}

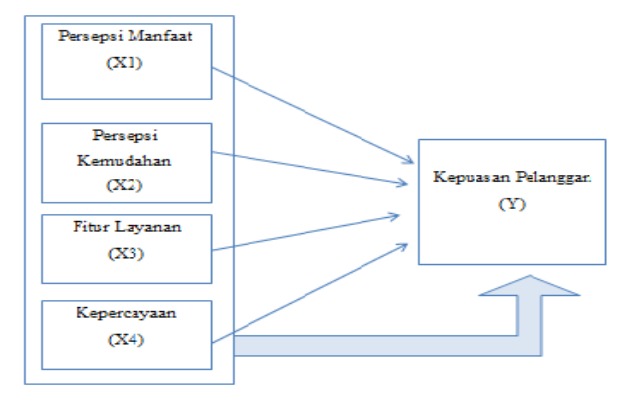

Sumber : Olahan penulis, 2019

Gambar 1. Kerangka Pemikiran

Keterangan :

$\longrightarrow$ Garis Pengujian Parsial Garis Pengujian Simultan
Davis (1989) mengemukakan perceived usefulness sebagai kepercayaan yang dimiliki seseorang dalam menggunakan teknologi dapat bermanfaat untuk meningkatkan suatu kinerja. Menurut Davis (1989) terdapat keterkaitan antara persepsi kegunaan dengan kepuasan pelanggan. Hal ini didukung dengan penelitian Chen-Ying Lee, et.,al (2015) perceived usefulness dan perceived ease of use secara positif mempengaruhi customer satisfaction.

Davis (1989) menjelaskan perceived ease of use adalah seberapa besar seseorang percaya bahwa menggunakan teknologi dapat dengan mudah diakses tanpa membutuhkan efforts yang banyak. Davis (1989) menyatakan bahwa terdapat keterkaitan antara persepsi kemudahan dengan kepuasan pelanggan. Hal ini didukung penelitian Zainudin $\mathrm{S}$ dan Paramitha S. (2014) yang menyatakan perceived ease of use menghasilkan pengaruh positif terhadap tingkat kepuasan nasabah.

Kotler dan Keller (2012) menjelaskan bahwa fitur adalah ciri khas produk yang dijadikan sebagai pelengkap dari fungsi produk tersebut. Teori Ferrinadewi (2005) menyatakan pula ada hubungan antara fitur atau atribut produk dengan kepuasan pelanggan. Hal ini didukung penelitian Angelos Pantouvakis (2013) menunjukkan customer satisfaction dipengaruhi oleh service features.

Kotler dan Keller (2016) mendefinisikan kepercayaan sebagai kesanggupan organisasi untuk dapat menciptakan hubungan dan dapat bergantung pada mitra bisnisnya, yang dipengaruhi oleh faktor interpersonal, integritas, kebaikan maupun kejujuran. Teori Costabile (2002) mengungkapkan bahwa terdapat hubungan antara kepercayaan dengan kepuasan pelanggan. Hal ini didukung penelitian Heri S (2016) dan Stefhani S. et al. (2015) yang menunjukkan variabel kepercayaan berpengaruh positif kepuasan nasabah. 
Berdasarkan kajian pustaka dan gambar kerangka berpikir diatas, didapatkan hipotesis penelitian yaitu "Persepsi Manfaat, Persepsi Kemudahan, Fitur Layanan, dan Kepercayaan berpengaruh terhadap Tingkat Kepuasan Pelanggan LinkAja di Indonesia baik secara parsial maupun simultan".

\section{METODE PENELITIAN}

\section{Jenis Penelitian}

Metode yang digunakan dalam penelitian ini adalah metode penelitian kuantitatif dengan analisis deskriptif dan kausal.

\section{Populasi dan Sampel}

Populasi yang dipilih yaitu pengguna aplikasi LinkAja di Indonesia yang datanya tidak diketahui, maka ukuran sampel ditentukan dengan metode Bernoulli sehingga total sampel 100 responden.

\section{Teknik Pengambilan Sampel}

Teknik sampling yang dipilih yaitu non probability sampling berjenis purposive sampling. Beberapa kriteria pada sampel ini ialah :

a) Pelanggan yang pernah melakukan transaksi dengan LinkAja.

b) Pelanggan yang pernah melakukan komplain atas gangguan pada saat melakukan transaksi.

c) Pelanggan yang pernah mendapatkan respon dan pelayanan langsung dari customer service LinkAja.

\section{Teknik Analisis Data}

Analisis data yang dipilih ialah deskriptif dan regresi linear berganda dengan skala pengukuran adalah skala likert.

\section{PEMBAHASAN}

\section{Uji Validitas dan Reliabilitas}

\section{Uji Validitas}

Uji validitas ditentukan dengan membandingkan nilai $r$-hitung dengan nilai $r-$ tabel. Jika r-hitung > r-tabel maka pernyataan valid. Hasil dari uji validitas ditunjukkan pada Tabel 1 :
Tabel 1 Uji Validitas

\begin{tabular}{|c|c|c|c|c|}
\hline Variabel & $\begin{array}{l}\mathrm{N} \\
\mathrm{O}\end{array}$ & $\begin{array}{c}\mathrm{R} \\
\text { Hitung }\end{array}$ & $\begin{array}{c}\mathrm{R} \\
\text { Tabel }\end{array}$ & $\begin{array}{c}\text { Keteranga } \\
n\end{array}$ \\
\hline \multirow{5}{*}{$\begin{array}{l}\text { Persepsi } \\
\text { Manfaat }\end{array}$} & 1 & 0,866 & 0,165 & Valid \\
\hline & 2 & 0,878 & 0,165 & Valid \\
\hline & 3 & 0,747 & 0,165 & Valid \\
\hline & 4 & 0,884 & 0,165 & Valid \\
\hline & 5 & 1 & 0,165 & Valid \\
\hline \multirow{6}{*}{$\begin{array}{c}\text { Persepsi } \\
\text { Kemudahan }\end{array}$} & 6 & 0,854 & 0,165 & Valid \\
\hline & 7 & 0,869 & 0,165 & Valid \\
\hline & 8 & 0,821 & 0,165 & Valid \\
\hline & 9 & 0,850 & 0,165 & Valid \\
\hline & 10 & 0,859 & 0,165 & Valid \\
\hline & 11 & 1 & 0,165 & Valid \\
\hline \multirow{6}{*}{$\begin{array}{c}\text { Fitur } \\
\text { Layanan }\end{array}$} & 12 & 0,829 & 0,165 & Valid \\
\hline & 13 & 0,874 & 0,165 & Valid \\
\hline & 14 & 0,903 & 0,165 & Valid \\
\hline & 15 & 0,868 & 0,165 & Valid \\
\hline & 16 & 0,905 & 0,165 & Valid \\
\hline & 17 & 1 & 0,165 & Valid \\
\hline \multirow{5}{*}{$\begin{array}{c}\text { Kepercayaa } \\
n\end{array}$} & 18 & 0,878 & 0,165 & Valid \\
\hline & 19 & 0,847 & 0,165 & Valid \\
\hline & 20 & 0,873 & 0,165 & Valid \\
\hline & 21 & 0,873 & 0,165 & Valid \\
\hline & 22 & 0,829 & 0,165 & Valid \\
\hline \multirow{5}{*}{$\begin{array}{l}\text { Kepuasan } \\
\text { Pelanggan }\end{array}$} & 23 & 1 & 0,165 & Valid \\
\hline & 24 & 0,900 & 0,165 & Valid \\
\hline & 25 & 0,839 & 0,165 & Valid \\
\hline & 26 & 0,870 & 0,165 & Valid \\
\hline & 27 & 0,835 & 0,165 & Valid \\
\hline
\end{tabular}




\begin{tabular}{|c|c|c|c|c|}
\hline & 28 & 0,833 & 0,165 & Valid \\
\cline { 2 - 5 } 29 & 0,873 & 0,165 & Valid \\
\cline { 2 - 5 } & 30 & 0,890 & 0,165 & Valid \\
\cline { 2 - 5 } & 31 & 0,861 & 0,165 & Valid \\
\cline { 2 - 5 } 32 & 0,883 & 0,165 & Valid \\
\cline { 2 - 5 } & 33 & 1 & 0,165 & Valid \\
\hline
\end{tabular}

Sumber : Output Olahan SPSS 20, 2019

Berdasarkan hasil Tabel 1 menunjukkan dari seluruh item pernyataan memiliki korelasi lebih tinggi daripada nilai batas sehingga dikatakan semua item valid.

Uji Reliabilitas

Uji reliabilitas ditentukan apabila $\alpha>0,60$ maka kuesioner dinyatakan reliabel. Hasil dari uji ini ditunjukkan pada Tabel 2:

Tabel 2 Uji Reliabilitas

\begin{tabular}{|l|c|c|}
\hline \multicolumn{1}{|c|}{ Variabel } & $\alpha$ & Hasil \\
\hline Persepsi Manfaat & 0,874 & Reliabel \\
\hline $\begin{array}{l}\text { Persepsi } \\
\text { Kemudahan }\end{array}$ & 0,925 & Reliabel \\
\hline Fitur Layanan & 0,937 & Reliabel \\
\hline Kepercayaan & 0,928 & Reliabel \\
\hline $\begin{array}{l}\text { Kepuasan } \\
\text { Pelanggan }\end{array}$ & 0,963 & Reliabel \\
\hline
\end{tabular}

Sumber : Output Olahan SPSS 20, 2019

Hasil uji reliabilitas pada Tabel 2 menunjukkan setiap variabel mempunyai $\alpha>$ 0,60 maka dapat disimpulkan semua item pernyataan reliabel.

\section{Teknik Analisis Data Statistik Deskriptif}

Statistik deskriptif bertujuan untuk menganalisis bagaimana tanggapan responden pada setiap variabel bebas maupun terikat. Terdapat lima kategori pengelompokkan persentase yaitu sangat baik, baik, kurang baik, buruk dan sangat buruk yang dapat disajikan pada gambar dibawah ini :

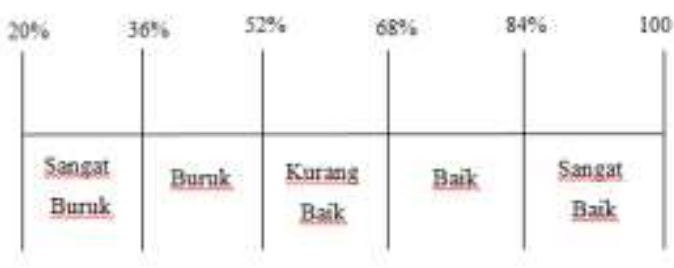

Sumber : Olahan Penulis, 2019

Gambar 2 Kategori Pengelompokkan Persentase

Berdasarkan pengujian SPSS, hasil dari setiap variabel disajikan dalam Tabel 3 :

Tabel 3 Tanggapan Responden Mengenai Variabel

\begin{tabular}{|l|l|c|c|}
\hline No & \multicolumn{1}{|c|}{ Variabel } & $\begin{array}{c}\text { Total } \\
\text { Skor }\end{array}$ & $\begin{array}{c}\text { Rata-rata } \\
\text { Persentase }\end{array}$ \\
\hline 1 & Persepsi Manfaat (X1) & 1.523 & $60,92 \%$ \\
\hline 2 & $\begin{array}{l}\text { Persepsi Kemudahan } \\
\text { (X2) }\end{array}$ & 2.023 & $67,43 \%$ \\
\hline 3 & Fitur Layanan (X3) & 1.785 & $59,50 \%$ \\
\hline 4 & Kepercayaan (X4) & 1.973 & $65,76 \%$ \\
\hline 5 & $\begin{array}{l}\text { Kepuasan Pelanggan } \\
\text { (Y) }\end{array}$ & 3.244 & $64,88 \%$ \\
\hline
\end{tabular}

Sumber : Output Olahan SPSS 20, 2019

Hasil tanggapan responden pada Tabel 3 menunjukkan variabel persepsi manfaat, persepsi kemudahan, fitur layanan, kepercayaan, dan kepuasan pelanggan termasuk dalam kategori kurang baik.

\section{Uji Normalitas}

Uji normalitas ditentukan dengan One Sample Kolmogorov Smirnov. Apabila nilai signifikan diatas 0,05 maka data berdistribusi normal, namun apabila nilai signifikan bibawah 0,05 maka data tidak berdistribusi normal. Hasil dari uji ini dapat dijelaskan pada Tabel 4 : 
Tabel 4 Uji Normalitas

\begin{tabular}{|c|c|c|c|}
\hline & Model & \multicolumn{2}{|c|}{ Collinearity Statistics } \\
\hline & & Tolerance & VIF \\
\hline \multirow{5}{*}{1} & (Constant) & & \\
\hline & Total_PM & 0.605 & 1.654 \\
\hline & Total_PK & 0.125 & 8.006 \\
\hline & Total_FL & 0.214 & 4.683 \\
\hline & Total_KC & 0.196 & 9.369 \\
\hline
\end{tabular}

Sumber : Output Olahan SPSS 20, 2019

Menurut hasil uji normalitas pada Tabel 4 dapat disimpulkan bahwa nilai tingkat signifikansi adalah 0,728 >0,05 maka data dapat dikatakan berdistribusi normal.

\section{Uji Heterokesdastisitas}

Pengujian ini untuk menganalisis ada atau tidaknya ketidaksamaan varian pada regresi linear. Berdasarkan pengujian SPSS, uji heterokedastisitas dijelaskan dalam Gambar 2 berikut:

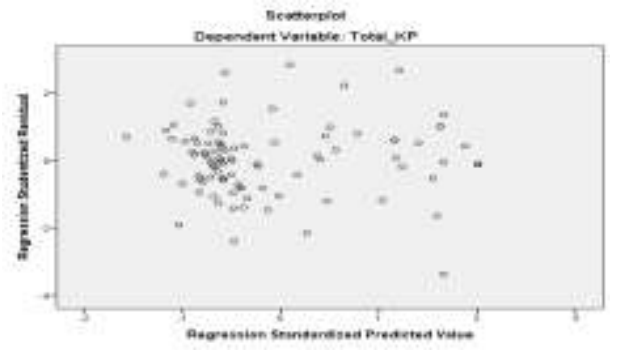

Sumber : Output Olahan SPSS 20, 2019

Gambar 1 Hasil Uji Heterokesdastisitas

Berdasarkan uji heterokesdastisitas pada Gambar 2 menunjukkan bahwa hasil titik scatterplot tidak ada pola yang jelas serta titik yang menyebar diatas, dibawah angka 0 pada sumbu Y sehingga disimpulkan tidak adanya heterokedastisitas.

\section{Uji Multikolinearitas}

Pengujian ini untuk mengetahui ada atau tidaknya hubungan antar variabel bebas.
Tabel 5 Uji Multikolinearitas

\begin{tabular}{|ll|c|}
\hline & & $\begin{array}{c}\text { Unstandardized } \\
\text { Residual }\end{array}$ \\
\hline $\mathrm{N}$ & Average & $0 \mathrm{E}-7$ \\
Normal & S. & 2.16637409 \\
Parameters & Deviation & \\
& Absolute & 0.069 \\
Most Extreme & Positive & 0.069 \\
Differences & Negative & -0.051 \\
Kolmogorov-Smirnov Z & 0.690 \\
Asymp. Sig. (2-tailed) & 0.728 \\
\hline
\end{tabular}

Sumber : Output Olahan SPSS 20, 2019

Pada Tabel 5 didapatkan hasil nilai tolerance pada semua variabel bebas $>0,1$ dan nilai VIF $<$ 10. Berdasarkan hasil tersebut, dapat dikatakan bahwa tidak terjadi multikolinearitas.

\section{Uji Regresi Linier Berganda}

Pengujian ini untuk menganalisis ada atau tidaknya pengaruh variabel independen terhadap variabel dependen. Hasil uji ini dijelaskan dalam Tabel 6 berikut :

Tabel 6 Analisis Regresi Linear Berganda

\begin{tabular}{|c|c|c|c|c|c|}
\hline \multirow{2}{*}{ Model } & \multicolumn{2}{|c|}{$\begin{array}{l}\text { Unstandardized } \\
\text { Coefficients }\end{array}$} & $\begin{array}{c}\text { Standar } \\
\text { dized } \\
\text { Coeffici } \\
\text { ents }\end{array}$ & \multirow{2}{*}{$\mathrm{t}$} & \multirow{2}{*}{ Sig. } \\
\hline & B & $\begin{array}{l}\text { Std. } \\
\text { Error }\end{array}$ & Beta & & \\
\hline (Constant & -0.643 & 1.023 & & -.629 & $\begin{array}{l}0.53 \\
1\end{array}$ \\
\hline Total_PM & 0.120 & 0.072 & 0.052 & $\begin{array}{l}1.66 \\
2\end{array}$ & $\begin{array}{l}0.00 \\
1\end{array}$ \\
\hline Total_PK & 0.442 & 0.119 & 0.255 & $\begin{array}{l}3.70 \\
9\end{array}$ & $\begin{array}{l}0.00 \\
0\end{array}$ \\
\hline Total_FL & 0.449 & 0.081 & 0.291 & $\begin{array}{l}5.54 \\
2\end{array}$ & $\begin{array}{l}0.00 \\
0\end{array}$ \\
\hline Total_KC & 0.725 & 0.133 & 0.428 & $\begin{array}{l}5.46 \\
9\end{array}$ & $\begin{array}{l}0.00 \\
0\end{array}$ \\
\hline
\end{tabular}

Sumber : Output Olahan SPSS 20, 2019 
Berdasarkan uji regresi linear pada Tabel 6, diperoleh persamaan :

$$
\begin{aligned}
\mathrm{Y} & =-0,643+0,120 \mathrm{X} 1+0,442 \mathrm{X} 2+ \\
& 0,449 \mathrm{X} 3+0,725 \mathrm{X} 4
\end{aligned}
$$

Berdasarkan persamaan regresi linear berganda diatas, maka diperoleh kesimpulan :

1) Konstanta : $-0,643$ jika semua variabel independen bernilai nol maka tingkat kepuasan pelanggan sebesar $-0,643$.

2) Persepsi manfaat : 0,120 maka terdapat hubungan positif antara persepsi manfaat terhadap tingkat kepuasan pelanggan karena terjadi peningkatan sebesar 0,120 .

3) Persepsi kemudahan : 0,442 maka terdapat hubungan positif antara persepsi kemudahan terhadap tingkat kepuasan pelanggan karena terjadi peningkatan sebesar 0,442 .

4) Fitur layanan : 0,449 maka terdapat hubungan positif antara fitur layanan terhadap tingkat kepuasan pelanggan karena terjadi peningkatan sebesar 0,449 .

5) Kepercayaan : 0,725 maka terdapat hubungan positif antara kepercayaan terhadap tingkat kepuasan pelanggan karena terjadi peningkatan sebesar 0,725 .

\section{Hasil Pengujian Hipotesis}

\section{1) Uji $\mathbf{t}$}

Tingkat signifikansi $(\alpha)$ sebesar sebesar 0,05 , $\mathrm{df}=\mathrm{k} ; \mathrm{n}-(\mathrm{k}+1) . \mathrm{df}=4 ; 100-(4+1)=95$ sehingga $t$ tabel sebesar 1,661. Hipotesis dalam penelitian dapat diterima jika $t$ hitung > $\mathrm{t}$ tabel. Penjelasan dari setiap variabel independen yaitu :

a) $\mathrm{X} 1$ terhadap $\mathrm{Y}$, nilai $\mathrm{t}$ hitung sebesar $1,662>1,661$ dan tingkat signifikansi $0,001<0,05$. Hasil tersebut menunjukkan hipotesis pertama diterima sehingga variabel persepsi manfaat berpengaruh positif dan signifikan terhadap kepuasan pelanggan. Hasil penelitian ini mendukung penelitian Yulisa Saptawati (2018) yang menunjukkan persepsi manfaat berpengaruh positif terhadap kepuasan nasabah. Davis (1989) juga menyatakan persepsi kegunaan akan mempengaruhi kepuasan dan loyalitas pelanggan.

b) X2 terhadap Y, nilai t hitung sebesar $3,709>1,661$ dan tingkat signifikansi $0,000<0,05$. Hasil tersebut menunjukkan hipotesis kedua diterima sehingga variabel persepsi kemudahan berpengaruh positif dan signifikan terhadap kepuasan pelanggan. Hasil penelitian ini mendukung penelitian Yulisa Saptawati (2018) yang menunjukkan persepsi kemudahan berpengaruh positif terhadap kepuasan nasabah. Davis (1989) juga menyatakan persepsi kemudahan penggunaan akan mempengaruhi kepuasan dan loyalitas pelanggan.

c) X3 terhadap $\mathrm{Y}$, nilai $\mathrm{t}$ hitung sebesar $5,542>1,661$ dan tingkat signifikansi $0,000<0,05$. Hasil tersebut menunjukkan hipotesis ketiga diterima sehingga variabel fitur layanan berpengaruh positif dan signifikan terhadap kepuasan pelanggan. Hasil penelitian ini mendukung penelitian Angelos Pantouvakis (2013) yang menunjukkan customer satisfaction dipengaruhi oleh service features. Teori Ferrinadewi (2005) menyatakan pula ada hubungan antara fitur atau atribut produk dengan kepuasan pelanggan.

d) $\mathrm{X} 4$ terhadap $\mathrm{Y}$, nilai $\mathrm{t}$ hitung sebesar $5,469>1,661$ dan tingkat signifikansi $0,000<0,05$. Hasil tersebut menunjukkan hipotesis keempat diterima sehingga variabel kepercayaan berpengaruh positif dan signifikan terhadap kepuasan pelanggan. Hasil penelitian ini mendukung penelitian Heri S (2016) dan Stefhani S. et al. (2015) yang menunjukkan variabel kepercayaan berpengaruh positif kepuasan nasabah. Selain itu teori Costabile (1989) mengungkapkan bahwa terdapat hubungan antara kepercayaan dengan kepuasan pelanggan.

\section{2) Uji F}

Pengujian ini untuk menganalisis ada atau tidaknya pengaruh simultan variabel bebas terhadap variabel terikat. 
Tabel 7 Hasil Uji F (Simultan)

\begin{tabular}{|c|c|c|c|c|c|}
\hline $\begin{array}{c}\text { Mode } \\
\text { I }\end{array}$ & $\begin{array}{c}\text { Sum } \\
\text { of } \\
\text { Squ } \\
\text { ares }\end{array}$ & df & $\begin{array}{c}\text { Mea } \\
\text { n } \\
\text { Squ } \\
\text { are }\end{array}$ & F & Sig \\
\hline $\begin{array}{c}\text { Regre } \\
\text { ssion }\end{array}$ & $\begin{array}{c}7824 \\
.016\end{array}$ & 4 & $\begin{array}{c}1956 \\
.004\end{array}$ & 399.9 & 0.000 \\
b \\
\hline $\begin{array}{c}\text { Resid } \\
\text { ual }\end{array}$ & $\begin{array}{c}464 . \\
624\end{array}$ & 95 & $\begin{array}{c}4.89 \\
1\end{array}$ & & \\
\hline Total & $\begin{array}{c}8288 \\
.640\end{array}$ & 99 & & & \\
\hline
\end{tabular}

Sumber : Output Olahan SPSS 20, 2019

Menurut hasil uji F Tabel 7 diperoleh F hitung $399,937>2,47$, dan hasil signifikansi $0,000<$ 0,05 . Sehingga disimpulkan bahwa terdapat pengaruh secara simultan variabel independen terhadap variabel dependen, oleh karena itu hipotesis kelima diterima.

\section{Hasil Uji Koefisien Determinasi}

Tujuan dari uji koefisien determinasi adalah untuk mengidentifikasi berapa total nilai dari pengaruh variabel bebas terhadap variabel terikat. Penjelasan hasil dari uji ini dapat dijelaskan dalam Tabel 8 :

Tabel 8 Uji Koefisien Determinasi

\begin{tabular}{|c|c|c|c|l|}
\hline Model & R & R Square & $\begin{array}{l}\text { Adjusted R } \\
\text { Square }\end{array}$ & $\begin{array}{l}\text { Std. } \\
\text { Error of } \\
\text { the } \\
\text { Estimate }\end{array}$ \\
\hline 1 & $0.972^{\mathrm{a}}$ & 0.944 & 0.942 & 2,212 \\
\hline
\end{tabular}

Sumber: Output Olahan SPPS 20, 2019

Hasil uji dalam Tabel 8 yaitu didapatkan hasil $\mathrm{R}$ senilai 0,972 dan $\mathrm{R} 2$ 0,944. Besarnya pengaruh variabel $\mathrm{X}$ terhadap variabel $\mathrm{Y}$ ditunjukkan oleh KD dengan perhitungan rumus berikut:

$$
\begin{aligned}
\mathrm{KD} & =\mathrm{R}^{2} \times 100 \% \\
& =0,972^{2} \times 100 \% \\
& =94,47 \%
\end{aligned}
$$

Berdasarkan nilai koefisien determinasi menunjukkan bahwa $94,47 \%$ variabel $\mathrm{Y}$ dipengaruhi oleh variabel $\mathrm{X}$ dan sisanya $5,53 \%$ merupakan variabel lain diluar penelitian yang tidak digunakan oleh penulis.

\section{PENUTUP}

Persepsi manfaat untuk pelanggan LinkAja berada pada kategori kurang baik. Pengambilan kesimpulan ini dapat ditentukan melalui hasil tanggapan responden pada variabel persepsi manfaat dengan persentase sebesar $60,92 \%$. Disarankan pihak LinkAja dapat terus meningkatkan faktor-faktor dari persepsi manfaat yang dapat mempengaruhi kepuasan pelanggan. Beberapa diantaranya adalah dengan lebih banyak menawarkan promo, cashback, dan point, meningkatkan kualitas kinerja aplikasi agar tidak terjadi gangguan yang menghambat transaksi, memperbanyak kerjasama dengan merchant/vendor pembayaran, dan faktorfaktor lain yang dapat memberikan manfaat kepada pelanggan LinkAja.

Persepsi kemudahan untuk pelanggan LinkAja berada pada kategori kurang baik. Pengambilan kesimpulan ini dapat ditentukan melalui hasil tanggapan responden pada variabel persepsi kemudahan dengan persentase sebesar 67,43\%. Disarankan pihak LinkAja dapat terus meningkatkan faktorfaktor dari persepsi kemudahan yang dapat mempengaruhi kepuasan pelanggan LinkAja. Beberapa diantaranya adalah dengan meningkatkan sistem aplikasi mengenai instruksi panduan penggunaan (upgrade, top up saldo, cara pembayaran, dll), memperbanyak kerjasama agar dapat mempermudah pelanggan melakukan transaksi diberbagai jenis pembayaran digital dengan menggunakan LinkAja, dan sebagainya. Selain itu, perusahaan juga perlu memahami keluhankeluhan serta mengutamakan keinginan pelanggan agar tercipta kemudahan dalam penggunaan aplikasi tersebut.

Fitur layanan untuk pelanggan LinkAja berada pada kategori kurang baik. Pengambilan kesimpulan ini dapat ditentukan melalui hasil tanggapan responden pada variabel fitur layanan dengan persentase sebesar 59,50\%. Disarankan pihak LinkAja dapat terus meningkatkan fitur layanan yang dapat mempengaruhi kepuasan pelanggan. Beberapa diantaranya adalah meningkatkan keunggulan fitur terutama pada fitur bayar merchant, bayar e-commerce (belanja online), dan pembayaran lainnya. Selain itu, meningkatkan kerjasama dengan berbagai merchant food and beverage 
yang banyak diminati oleh masyarakat juga diperlukan.

Kepercayaan untuk pelanggan LinkAja berada pada kategori kurang baik. Pengambilan kesimpulan ini dapat ditentukan melalui hasil tanggapan responden pada variabel kepercayaan dengan persentase sebesar 65,76\%. Disarankan pihak LinkAja dapat terus meningkatkan kepercayaan pelanggan dalam memberikan layanan e-money. Seperti memperhatikan keluhan dan masukan pelanggan mengenai keamanan setiap transaksi, refund dana transaksi yang gagal dengan cepat, menyediakan merchant/vendor yang diakui eksistensinya, meningkatkan pelayanan customer service LinkAja, dan faktor-faktor lain yang dapat meningkatkan kepercayaan pelanggan LinkAja.

Tingkat kepuasan pelanggan LinkAja berada pada kategori kurang baik. Pengambilan kesimpulan ini dapat ditentukan melalui hasil tanggapan responden pada variabel kepuasan pelanggan dengan persentase sebesar $64,88 \%$. Disarankan pihak LinkAja dapat terus meningkatkan hal-hal yang dapat berpengaruh baik pada kepuasan pelanggan dalam penggunaan aplikasi e-money. Seperti memperbaiki dan meningkatkan fitur atau layanan, memperbanyak promo dan diskon, menawarkan harga yang sesuai dengan manfaat, memiliki keunggulan kompetitif yang berbeda dengan pesaing, dan hal-hal lain.

Hasil uji $\mathrm{F}$ dan Uji $\mathrm{t}$ menjelaskan bahwa variabel persepsi manfaat, persepsi kemudahan, fitur layanan, dan kepercayaan secara simultan dan parsial berpengaruh positif dan signifikan terhadap tingkat kepuasan pelanggan LinkAja di Indonesia. Sedangkan besarnya pengaruh variabel $\mathrm{X}$ terhadap variabel $\mathrm{Y}$ adalah $94,47 \%$ dan sisanya $5,53 \%$ merupakan variabel lain diluar penelitian.

\section{REFERENSI}

Akdon, \&. R. (2013). Rumus dan Data Dalam Analisis Statistika. Bandung: Alfabeta.

Angelos Pantouvakis \& Nancy Bouranta. (2013). The interrelationship between service features, job satisfactionand customer satisfaction
Evidence from the transport sector. Emerald Group Publishing: The TQM Journal. Volume 25, Issue 2 doi:10.1108/17542731311299618

Costabile, M., et al. (2002). A Dynamic Model of Customer Loyalty. Proceedings of the $31^{\text {st }}$ Annual Conference of the European Marketing Academy.

Davis, F. D. 1989. Perceived usefulness, perceived ease of use, and user acceptance of information technology. MIS Quarterly.

Ferrinadewi, Erna. (2005). Atribut Produk yang Dipertimbangkan dalam Pembelian Kosmetik dan Pengaruhnya pada Kepuasan Konsumen di Surabaya. Jurnal Manajemen \& Kewirausahaan. Vol.7.no.2.pp.139-151. https://doi.org/10.9744/jmk.7.2.pp.\%2 0139-151

Kotler, \& Keller. (2012). Manajemen Pemasaran. Edisi 12. Jakarta: Erlangga.

Kotler, Phillip dan Kevin L. Keller. (2016). Marketing Management 16 edition. England : Pearson Education, Inc.

Setyo Ferry W, D. R. (2015). Pengaruh Persepsi Manfaat, Persepsi Kemudahan, Fitur Layanan, dan Kepercayaan terhadap Minat Menggunakan E-Money Card (Studi pada Pengguna Jasa Commuterline di Jakarta. Jurnal Riset Manajemen Sains Indonesia (JRMSI) | Vol. 6, No. 1, 2015. https://doi.org/10.21009/JRMSI.006.1 .06

Sugiyono. (2016). Metode Penelitian Kuantitatif, Kualitatif dan $R \& D$. Bandung: PT Alfabet.

Thom W.A. Isliko \& Mintarti Rahayu. (2008). Mediasi Keputusan Pembelian pada Pengaruh Faktor Situasional dan Faktor Produk terhadap Kepuasan Konsumen Supermarket di Kota Lampung. Jurnal Aplikasi 
Manajemen, $\quad 8(2)$ : pp: 11-15. https://jurnaljam.ub.ac.id/index.php/ja $\mathrm{m} /$ issue/view/16.

Zainudin, S. \& Paramitha Sandana. (2014). Analisis Pengaruh Perceived Usefulness dan Perceived Ease Of Use terhadap Tingkat Kepuasan Nasabah dalam Menggunakan ATM (Studi Kasus pada Nasabah Bank Muamalat Cab. Palopo). Jurnal Muamalah, vol 4. http://ejournal.iainpalopo.ac.id/index. php/muamalah/article/view/645

\section{BIODATA PENULIS}

Findy Meileny, lahir di Grobogan 15 Mei 1997 merupakan Mahasiswa S1 jurusan Administrasi Bisnis di Universitas Telkom Bandung-lulus tahun 2020. Memiliki ketertarikan pada bidang bisnis dan manajemen.

Tri Indra Wijaksana, adalah dosen tetap di Universitas Telkom Bandung. Menyelesaikan Program S1 dengan bidang Ilmu Administrasi Bisnis, Universitas Padjajaran dan Program Pasca Sarjana dengan bidang Administrasi Bisnis di Universitas Padjajaran. 
